\title{
Del otro lado de las cenizas
}

\author{
No llores por las noches \\ en que llueve; \\ fija tus ojos \\ en el agua del suelo.
}

La lluvia enterrará tu dolor en el fondo de la tierra.

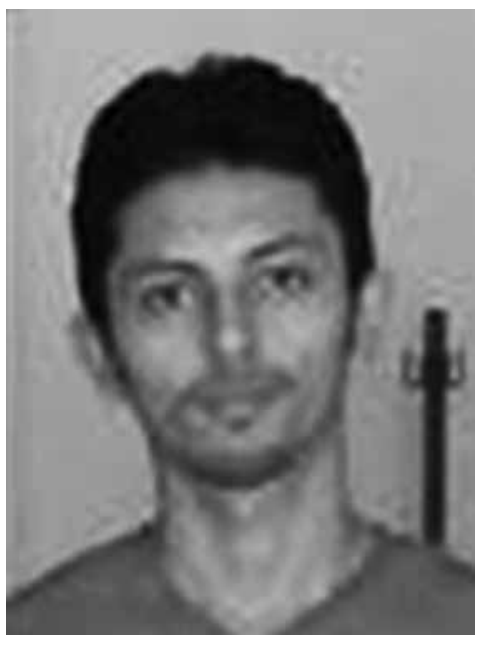

Eddy Alfonso Salgado López

Nace en la ciudad de Siuna el 27 de noviembre de 1991.

En el 2009 concluye sus estudios de secundaria y en el 2010 ingresa a la universidad UNAN-León, a la carrera de Inglés. Se gradúa en el 2014 y el siguiente año es profesor horario a la universidad URACCANSiuna, donde diseña e imparte cursos de escritura creativa. Tú dolor en el fondo de la tierra. 